\title{
HUBUNGAN POLA ASUH DENGAN KEJADIAN KEKERASAN TERHADAP ANAK USIA SEKOLAH (6-18 TAHUN) DI KELURAHAN DUFA-DUFA KECAMATAN TERNATE UTARA
}

\author{
Fataruba R., Purwatiningsih S., Wardani Y \\ Fakultas Kesehatan Masyarakat, Universitas Ahmad Dahlan, Yogyakarta
}

\begin{abstract}
Background : Parents are the first and best teachers in the process of the human being's behavior, parenting if properly understood by parents so children grow and develop into a good figure but if the parent's upbringing of children is wrong will impact on bad boy behavior. In the village Dufa-dufa Northern Distict of Ternate in North Maluku LPA survey Januari-Desember 2008 cases of child violence in the form violence physical (70 cases), sexual violence (3 cases), psychological violence (76 cases), economic exploitation/child labor (17 cases), sexual exploitation of children (1 cases), the child victims of conflict areas (15 cases), sexual abuse (4 cases), neglect of children (20 cases), murder ( 3 cases), the care and guardianship (12 cases). Purpose of this research is to determine whether there is a relationship parenting and violence against children at school age (6-18 years) in Dufa-dufa village Ternate northern districts.

Methods: This study was a quantitative non experimental by using cross-sectional design in data collection, research using the questionnaire ad a data collection instrument, respondents in this study were parents who have children of school age, the number of 187 samples sample.

Results: From the results of the statistic is obtained asymp sig number 0,000 . Results of these tests showed $\mathrm{P}<\alpha(0,000<0,05)$ so that $\mathrm{H}_{0}$ is reject can in inflict that there was a significant association between parenting style and the incidents of violence against children, because the amount of views from $C$ (coefficient contingency) is 28,8 percent for the contributed to variable parenting parents while the rest of the other variables not examined in this study

Conclusion: There was a significant relationship between parenting style and the incidents of violence against children in Dufa-dufa village Ternate Northern districts.
\end{abstract}

Keywords: Parenting, Genesis, Violence Against Children, School Age (6-18 Years).

\section{PENDAHULUAN}

UU Nomor 2 tahun 1989 tentang Sistem Pendidikan Nasional Pasal 10 ayat 4 dinyatakan bahwa: pendidikan keluarga merupakan bagian dari jalur pendidikan luar sekolah yang diselenggarakan dalam keluarga dan yang memberikan keyakinan agama, nilai budaya, nilai moral, dan keterampilan. Peralihan bentuk pendidikan jalur luar sekolah ke jalur pendidikan sekolah (formal) memerlukan "kerja sama" antara orang tua dan sekolah. Orang tua dapat menanamkan benih kebatinan yang sesuai dengan kebatinannya sendiri ke dalam jiwa anak-anaknya. Hak orang tua yang utama dan tidak dapat dibatalkan oleh orang lain ${ }^{1 .}$

Orang tua beranggapan bahwa melarang anak dengan cara memukul, merupakan cara yang paling ampuh. Pukulan akan memberikan suatu perasaan tidak enak pada anak. Hukuman-hukuman fisik seberapapun ringannya, akan memberikan akibat buruk bagi perkembangan anak. ${ }^{2}$ Anak di Indonesia usia 6-12 tahun paling sering mengalami kekerasan seksual (33\%) dan emosional (28,8\%), dibandingkan dengan kekerasan yang bersifat fisik $(24,1 \%)$. Ruang kekerasan terhadap anak sebagian besar terjadi di rumah (129 kasus), selanjutnya di jalanan (79), sekolah (10), lembaga keagamaan (2), sektor perekonomian (21), kekerasan seksual juga terjadi tidak hanya di rumah $(48,7 \%)$, di tempat umum $(6,1 \%)$, sekolah $(4,1 \%)$, tempat kerja $(3,0 \%)$, lain-lain $(0,4 \%){ }^{3}$ 


\section{METODE PENELITIAN}

Penelitian ini merupakan penelitian non eksperimental dengan menggunakan rancangan cross sectional. Populasi dalam penelitian ini adalah yaitu orang tua yang memiliki anak yang berusia 6-18 tahun. Jumlah sampel dalam penelitian ini sebanyak 187 yang berasal dari dari orang tua yang tinggal di kelurahan Dufa-dufa Kecamatan Ternate Utara. Cara pengambilan sampel secara probability sampling dengan teknik Stratified random sampling. Data dianalisis secara univariat dan bivariat. Analisis bivariat menggunakan uji $\mathrm{X}^{2}$.

\section{HASIL PENELITIAN DAN PEMBAHASAN}

\section{a. Hasil Penelitian}

1) Distribusi Responden

Tabel 1. Distribusi Frekuensi Responden di Kelurahan Dufa-dufa Kecamatan Ternate Utara

\begin{tabular}{|c|c|c|}
\hline Karakteristik & Jumlah & Presentase (\%) \\
\hline \multicolumn{3}{|l|}{ Umur anak: } \\
\hline $\begin{array}{l}-6-12 \text { tahun } \\
-13-15 \text { tahun } \\
-16-18 \text { tahun }\end{array}$ & $\begin{array}{l}57 \\
69 \\
61\end{array}$ & $\begin{array}{l}30,5 \\
36,4 \\
33,2\end{array}$ \\
\hline \multicolumn{3}{|l|}{ Jenis kelamin anak } \\
\hline $\begin{array}{l}\text { - Laki-laki } \\
\text { - Perempuan }\end{array}$ & $\begin{array}{l}95 \\
92\end{array}$ & $\begin{array}{l}50,8 \\
49,2\end{array}$ \\
\hline \multicolumn{3}{|l|}{ Pendidikan terakhir ayah: } \\
\hline $\begin{array}{l}\text { - SD } \\
\text { - SMP } \\
\text { - SMA } \\
\text { - Perguruan Tinggi }\end{array}$ & $\begin{array}{c}7 \\
11 \\
60 \\
109\end{array}$ & $\begin{array}{c}3,7 \\
5,9 \\
32,1 \\
58,1\end{array}$ \\
\hline \multicolumn{3}{|l|}{ Pendidikan terakhir ibu: } \\
\hline $\begin{array}{l}\text { - SD } \\
\text { - SMP } \\
\text { - SMA } \\
\text { - Perguruan Tinggi }\end{array}$ & $\begin{array}{l}16 \\
11 \\
95 \\
65\end{array}$ & $\begin{array}{c}6,8 \\
5,9 \\
50,8 \\
34,8\end{array}$ \\
\hline \multicolumn{3}{|l|}{ Pendapatan keluarga: } \\
\hline $\begin{array}{l}-<700.000 \\
-500.000-1.000 .000 \\
->1.000 .000\end{array}$ & $\begin{array}{c}21 \\
32 \\
134\end{array}$ & $\begin{array}{l}11,2 \\
17,1 \\
71,7\end{array}$ \\
\hline \multicolumn{3}{|l|}{ Pekerjaan ayah : } \\
\hline $\begin{array}{l}\text { - PNS } \\
\text { - Wiraswasta } \\
\text { - Nelayan }\end{array}$ & $\begin{array}{c}105 \\
71 \\
11\end{array}$ & $\begin{array}{c}56,1 \\
38,0 \\
5,9\end{array}$ \\
\hline \multicolumn{3}{|l|}{ Pekerjaan ibu : } \\
\hline $\begin{array}{l}\text { - PNS } \\
\text { - Wiraswasta } \\
\text { - Ibu Rumah Tangga }\end{array}$ & $\begin{array}{c}64 \\
22 \\
101\end{array}$ & $\begin{array}{l}34,2 \\
11,8 \\
54,0\end{array}$ \\
\hline Total & 187 & $100 \%$ \\
\hline
\end{tabular}

Berdasarkan tabel 1 dapat dijelaskan distribusi responden berdasarkan umur anak didominasi oleh yang berusia 13-15 tahun sebanyak 69 orang (36,4 persen) dan yang terendah yang berusia 6-12 tahun sebanyak 57 orang $(30,5$ persen). Distribusi responden berdasarkan jenis kelamin anak laki-laki sebanyak 
95 orang (50,8 persen) dan jenis kelamin perempuan sebanyak 92 orang $(49,2$ persen).

Distribusi responden berdasarkan pendidikan terakhir ayah didominasi oleh responden yang lulusan Perguruan Tinggi sebanyak 109 orang $(58,1$ persen) dan yang terendah yang lulusan Sekolah Dasar sebanyak 7 orang $(3,7$ persen). Distribusi responden berdasarkan pendidikan terakhir ibu didominasi oleh responden yang lulusan Sekolah Menengah Atas sebanyak 95 orang $(50,8$ persen) dan yang terendah yang lulusan Sekolah Menengah Pertama sebanyak 11 orang $(5,9$ persen).

Distribusi responden berdasarkan pendapatan keluarga didominasi oleh responden yang berpendapatan keluarga $>1.000 .000$ sebanyak 134 keluarga (71,7 persen) dan yang terendah yang berperndapatan keluarga $<700.000$ sebanyak 21 keluarga (11,2 persen). Distribusi responden berdasarkan pekerjaan ayah didominasi oleh responden yang pekerjaan sebagai PNS sebanyak 105 orang (56,1 persen) dan yang terendah yang pekerjaan sebagai nelayan sebanyak 11 orang (5,9 persen). Distribusi responden berdasarkan pekerjaan ibu didominasi oleh responden yang pekerjaan sebagai ibu rumah tangga sebanyak 101 orang (54,0 persen) dan yang terendah yang pekerjaan sebagai wiraswasta sebanyak 22 orang (11,8 persen).

2) Distribusi Frekuensi Variabel Penelitian

Analisis distribusi frekuensi pola asuh dan kejadian kekerasan terhadap anak usia sekolah di Kelurahan Dufa-Dufa Kecamatan Ternate Utara dapat dilihat pada tabel 2 berikut.

Tabel 2. Analisis Univariat Responden Pola Asuh dan Kejadian Kekerasan Terhadap Anak Usia Sekolah (6-18 tahun) di Kelurahan Dufa-dufa Kecamatan Ternate Utara

\begin{tabular}{lcc}
\hline \multicolumn{1}{c}{ Karakteristik } & Jumlah & Presentase (\%) \\
\hline Pola asuh : & & \\
- Permisif & 72 & 38,5 \\
- Otoriter & 13 & 7,0 \\
- Demokratis & 102 & 54,5 \\
Kekerasan terhadap anak : & & \\
- Mengalami kekerasan & 91 & 48,7 \\
- Tidak mengalami kekerasan & 96 & 51,3 \\
\hline \multicolumn{1}{c}{ Total } & 187 & $100 \%$ \\
\hline
\end{tabular}

Dari tabel 2 diatas didapatkan pola asuh demokratis 102 keluarga (54,5 persen) dan yang paling rendah menerapkan pola asuh otoriter sebanyak 13 keluarga ( 7,0 persen), Berdasarkan kekerasan terhadap anak yang mengalami kekerasan sebanyak 91 anak (48,7 persen) dan anak yang tidak mengalami kekerasan sebanyak 96 anak (51,3 persen).

3) Hubungan Antara Variabel Bebas Dengan Variabel Terikat

Hasil analisis bivariat hubungan pola asuh dengan kejadian kekerasan terhadap anak usia sekolah (6-18 tahun) di Kelurahan Dufa-dufa Kecamatan Ternate Utara adalah sebagai berikut: 
Tabel 3. Hasil Tabulasi Silang Variabel Penelitian

\begin{tabular}{lccc}
\hline & Value & Asymp. Sig. (2-sided) & Contingency Coefficient \\
\hline Pearson Chi-Square & $16,855(\mathrm{a})$ &, 000 &, 288 \\
\hline & & & 187 \\
\hline
\end{tabular}

Hasil pada tabel 3 hasil uji statistik didapatkan nilai chi-square $\left(\mathrm{X}^{2}\right)$ hitung $>$ dari $X^{2}$ tabel dengan rincian $16,855>3,481$, dan angka $P$ value dengan $\alpha(0,05 \%)$ dengan rincian $\mathrm{P}<\alpha(0,000<0,05)$. Ini berarti $\mathrm{H}_{0}$ ditolak yang dapat diambil kesimpulan bahwa ada hubungan yang signifikan antara pola asuh orang tua denga kejadian kekerasan terhadap anak usia sekolah (6-18 tahun), dilihat dari C (coefisien contingency) berarti sebesar 28,8 persen yang disumbangkan untuk variabel pola asuh orang tua terhadap kejadian kekerasan terhadap anak usia sekolah (6-18 tahun) sedangkan sisa variabel lain tidak diteliti dalam penelitian ini.

\section{b. Pembahasan}

1) Deskripsi Pola Asuh Responden

Responden yang digunakan dalam penelitian ini adalah orang tua yang memiliki anak usia sekolah (6-18 tahun) yang tinggal di Kelurahan Dufa-dufa yang berjumlah 351 orang. Sampel diambil dengan menggunakan pemilihan acak dan didapatkan hasil akhir sebanyak 187 orang.

Di pengaruhi dari karakteristik responden yaitu pendidikan terakhir ayah yang sebagian besar perguruan tinggi sebanyak 109 orang (58,1 persen), dan pendapatan keluarga yang sebagian besar responden memiliki pendapatan $>1.000 .000$ sebanyak 134 keluarga (71,7 persen). Jadi dapat disimpulkan bahwa dari 187 orang tua sudah menyadari pola asuh yang baik.

2) Kejadian Kekerasan Terhadap Anak Usia Sekolah (6-18 Tahun)

Kekerasan terhadap anak usia sekolah Kelurahan Dufa-dufa didominasi oleh anak yang tidak mengalami kekerasan 96 anak (51,3 persen), tetapi jumlah anak yang mengalami kekerasan cukup memprihatinkan yaitu sebanyak 91 anak (48,7 persen). Kekerasan yang dialami oleh anak usia sekolah di Kelurahan Dufa-dufa dipengaruhi oleh karakteristik responden yaitu pendidikan terakhir ibu sebagian besar lulusan SMA sebanyak 95 orang (50,8 persen).

Responden ibu di Kelurahan Dufa-dufa dengan lulusan SMA, pendidikan ibu tidak seimbang dengan pendidikan ayah yaitu perguruan tinggi ditunjang lagi saat wawancara terbatas sebagian besar ibu berusia muda, secara psikologis belum siap dalam membina keluarga. Ibu belum memiliki kesiapan dalam merawat anak, dikarenakan usia dan pendidikan ibu. Selain pendidikan dan usia ibu yang menyebabkan kasus kekerasan anak juga latar belakang budaya yang keras di daerah Dufa-dufa, selama penelitian ditemukan anak yang menangis kesakitan karena dipukul oleh orang tua dan anak yang kurang percaya diri saat orang tua mengomeli di depan umum.

Anak usia sekolah masih mencari jati diri dan masih labil dalam bersikap, sehingga anak usia sekolah masih sering melakukan kesalahan yang dapat memicu orang tua menjadi marah, sehingga orang tua menghukum anak tanpa mempertimbangkan dampak dari hukuman yang diberikan kepada anak. Sebaiknya orang tua menyadari masih banyak cara penyelesaian dalam 
menangani kesalahan yang diperbuat anak agar tidak melakukan kesalahan yag sama.

3) Hubungan Pola Asuh Dengan Kejadian Kekerasan Terhadap Anak Usia Sekolah (6-18 Tahun)

Hasil penelitian pola asuh dan kejadian kekerasan terhadap anak usia sekolah (6-18 tahun) diperoleh hasil ada hubungan yang signifikan dilihat dari nilai chisquare $\left(X^{2}\right)$ hitung $>$ dari $X^{2}$ tabel dengan rincian $16,855>3,481$, dan angka $P$ value dengan $\alpha(0,05 \%)$ dengan rincian $P<\alpha(0,000<0,05)$ yang menunjukkan bahwa ada hubungan yang bermakna pola asuh dengan kejadian kekerasan terhadap anak usia sekolah (6-18 tahun)

Peranan orang tua dalam pembentukan karakter anak sangat penting, setiap anak memiliki karakter yang berbeda hal ini sangat dipengaruhi oleh lingkungan keluarga. Banyak faktor yang memicu terjadinya kekerasan pada anak, orang tua memiliki alasan dalam menyelesaikan masalah anak dengan kekerasan misalnya kenakalan anak dan keadaan internal keluarga.

\section{SIMPULAN DAN SARAN}

\section{a. Simpulan}

1) Orang tua yang menerapkan pola asuh demokratis dalam keluarga yaitu 102 keluarga (54,5 persen), orang tua yang menerapkan pola asuh permisif dalam keluarga 72 keluarga (38,5 persen), dan orang tua yang menerapkan pola asuh otoriter dalam keluarga 13 keluarg (7,0 persen).

2) Anak yang mengalami kekerasan usia sekolah yaitu sebanyak 91 anak $(48,7$ persen), dan anak yang tidak mengalami kekerasan yaitu sebanyak 96 anak (51,3 persen).

3) Dari hasil penelitian mengenai hubungan pola asuh dan kejadian kekerasan terhadap anak usia sekolah (6-18 tahun) Kelurahan Dufa-dufa Kecamatan Ternate Utara dapat dismpulkan bahwa ada hubungan yang bermakna antara pola asuh dan kejadian kekerasan terhadap anak usia sekolah (6-18 tahun).

b. Saran

1) Bagi orang tua yaitu:

a) Membuka pengetahuan ibu di Kelurahan Dufa-dufa dengan mengadakan penyuluhan dan pengenalan mengenai kekerasan lewat radio, talk show dll sehingga wawasan ibu terbuka mengenai pola asuh dan kekerasan anak.

b) Kelurahan Dufa-dufa kebanyakan ibu berusia muda maka perlu perhatian pemerintah setempat untuk meningkatkan usia pernikahan yaitu $>20$ tahun.

2) Untuk penelitian selanjutnya di harapkan meneliti variabel yang belum diteliti yaitu variabel informasi, budaya, dan pengalaman dari orang tua.

\section{DAFTAR PUSTAKA}

1. Lask, Bryan., Memahami dan Mengatasi Masalah Anak Anda, Gramedia Pustaka Utama, Jakarta.1991

2. Rinestaelsa, at all, Hubungan Pola Asuh Orang Tua dengan Prestasi Belajar Siswa SMA Negeri 3 Yogyakarta, Skripsi, Tidak Dipublikasikan, Universitas Gadjah Mada, Yogyakarta.2008

3. Shochib, Moh., Pola Asuh Orang Tua dalam Membantu Anak Mengembangkan Disiplin Diri,Rineka Cipta, Jakarta.2000 


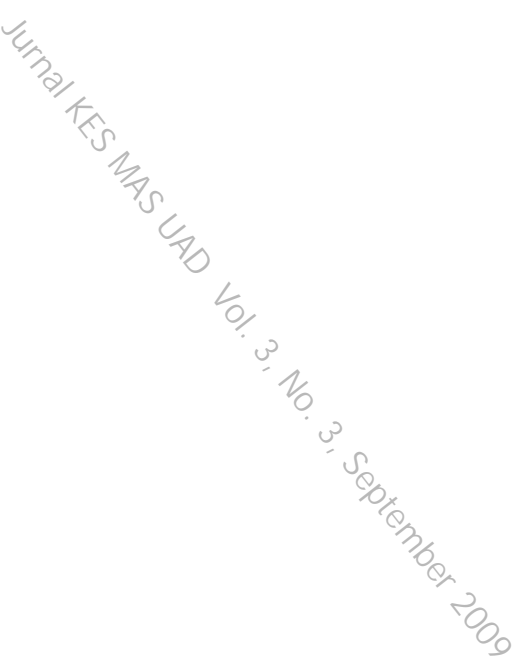

KES MAS Vol. 3, No. 3, September 2009 : 162-232 